\author{
Valeriia Lazorenko, \\ Sumy, Ukraine \\ (iD) ORCID, 0000-0001-5584-8074 \\ e-mail: valery2210987@gmail.com \\ Liudmyla Saher, \\ Ph.D., Associate Professor, Sumy State University, Ukraine \\ ORCID ID, 0000-0002-5628-5477 \\ e-mail: I.sager@kmm.sumdu.edu.ua \\ Adam Jasnikowski, \\ Bystrzyca Kłodzka, Poland \\ D ORCID ID, 0000-0002-5695-2364 \\ e-mail: adameuroweek@gmail.com
}

Correspondence author: I.sager@kmm.sumdu.edu.ua

\title{
WEB MANAGEMENT AS A MARKETING MANAGEMENT DETERMINANT: CASE FOR PHARMACEUTICAL ENTERPRISES
}

Abstract. Nowadays, the online business is fast-growing since it is convenient, more profitable, and less energyconsuming. The changing consumers' needs force companies and organizations to adjust and modernize their marketing strategies. The authors emphasized that Internet advertising channels would overcome the traditional ones. Therefore, it is relevant to consider the latest trends in e-commerce to provide effective advertising campaigns. This study aims to conduct the competitive analysis of Ukrainian veterinary enterprises' websites as one of the key marketing management determinants. The study object are the most prominent Ukrainian veterinary enterprises. The methodological basis for this paper includes trend, bibliometric, and comparative content analysis. The trend analysis results showed a constant interest in web management worldwide. In turn, there are significant fluctuations over the previous five years in Ukraine. The findings indicated that search requests for «pharmaceutics» worldwide are gradually increasing, while there is not enough statistic data in Ukraine. The bibliometric analysis for Scopus publications addressed the marketing management in the pharmaceutical were visualized by 4 clusters. The first cluster covers marketing, management, and risk issues; the second - pharmaceutical industry, the third - economy; and the fourth - quality control. The findings showed that veterinary medicine was mostly associated with drug efficacy, management, investment, management, risk, organization and management, patents, and quality control. This issue has been most actively studied by scientists from the United States, Britain, Germany, India, and Italy. This study provided the comparative analysis of veterinary enterprises web sites based on the main indicators as follows: usability, site structure, site indexation, number of external pages, overall traffic, behavioral factors (bounce rate, pages per visit, time on site), traffic sources (direct, referrals, SEO, SMM, e-mail, and display advertising), and adaptability to the mobile versions. The obtained results showed that all Ukrainian biological vaccines manufacturers for animals were represented on the Internet. In turn, as of September 2020, Biotestlab most effectively used the Internet to promote products. In second place is the Sumy Biological Factory, and then - Kherson Biological Factory.

Keywords: marketing, web management, determinant, enterprise, website, competitive analysis.

Introduction. The companies constantly improve their production and marketing activities to increase the efficiency of goods promotion. Amidst globalization and digitalization, the economy needs significant changes, mainly using the latest web management tools. It is worth emphasizing that business success is impossible under the globalization of world markets without purposeful communication activities to inform consumers about the company and its products widely. Therefore, the consumer purchase decision-

Cite as: Lazorenko, V., Saher, L., \& Jasnikowski, J. (2021). Web Management as a Marketing Management Determinant: Case for Pharmaceutical Enterprises. Health Economics and Management Review, 2, 105 114. http://doi.org/10.21272/hem.2021.2-10

105 
V., Lazorenko, L., Saher, J., Jasnikowski. Web Management as a Marketing Management Determinant: Case for Pharmaceutical Enterprises

making process should be thoroughly researched and straightforward for producers. Remarkably, this issue is especially relevant for products designed for a narrow target audience.

It stands to note that veterinary products focus mainly on veterinary clinic employees, agricultural enterprises, and less often, the final consumer. Accordingly, web management tools (primarily the website) must meet the criteria of clarity, informativeness, ease of use and information retrieval, etc.

Literature Review. Web management is a relevant issue for various fields. Figure 1 demonstrates the growth in the popularity of the search request «web management» for the last 5 years (2016-2021) using Google Trends. The study was conducted on June 22, 2021.

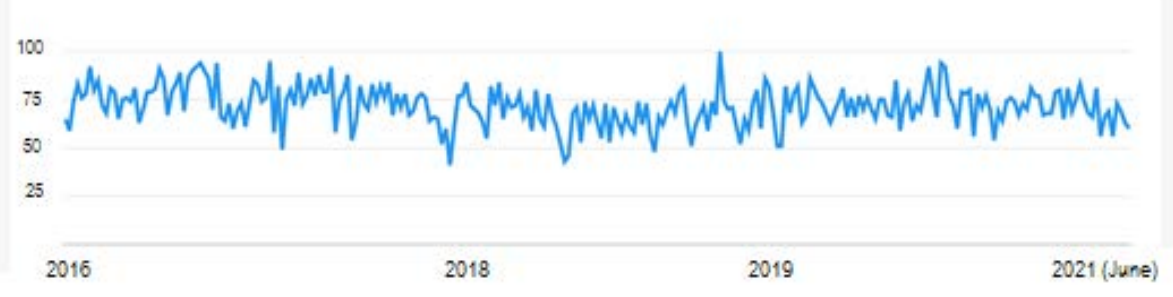

Figure 1. Dynamics of the search request «web management» worldwide Sources: developed by the authors using Google Trends.

Figure 1 shows that the request dynamic is relatively stable because there is no rapid growth or significant decline. Therefore, the popularity of the search request among the society confirms the relevance of web management tools. During the study period, the lowest mark was 41 percent in June 2018. On the other hand, in Ukraine, the data are slightly different. Besides, there is a significant fluctuation in requests from 0 to $100 \%$ and vice versa.

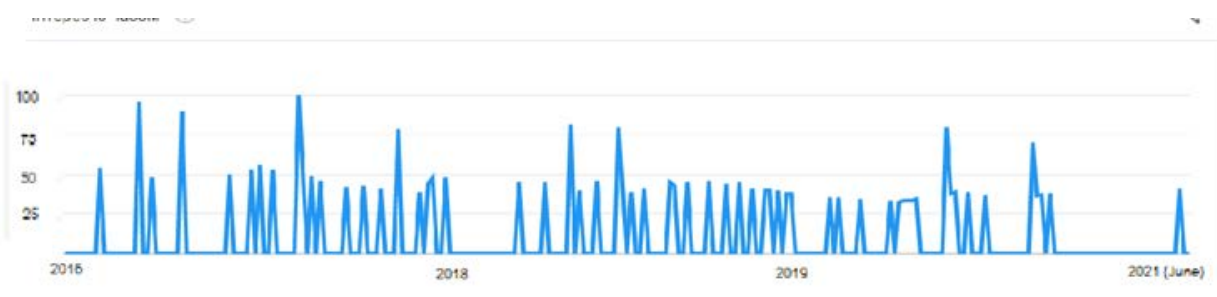

Figure 2. Dynamics of the search request «web management» in Ukraine Sources: developed by the authors using Google Trends.

Figure 3 visualizes the dynamics of the search request «pharmaceutics».

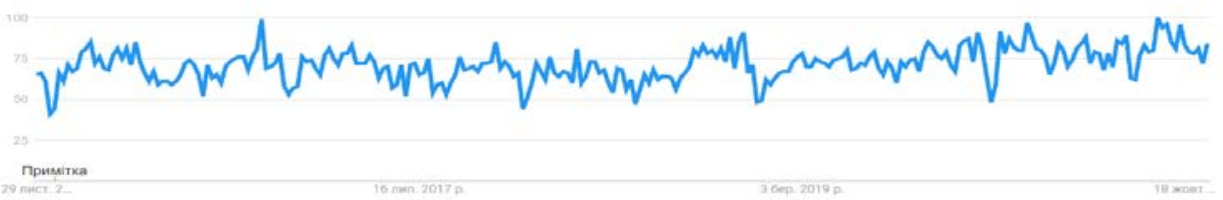

Figure 3. Dynamics of the search request «pharmaceutics» worldwide Sources: developed by the authors using Google Trends. 
V., Lazorenko, L., Saher, J., Jasnikowski. Web Management as a Marketing Management Determinant: Case for Pharmaceutical Enterprises

Figure 3 demonstrates the growing number of searches for «pharmaceutics» worldwide. Notably, the gradual growth of «pharmaceutical» search requests worldwide has begun since March 2019. At the same time, there is not enough data to estimate the situation in Ukraine.

This study involved analyzing the scientific treatises presented in the Scopus database to explore the general development trends of web management and marketing in the pharmaceutical over the last decade. For a broader and more in-depth analysis, the search was conducted under the keyword «marketing management». That allowed figuring out the general research areas in marketing management and promotion in pharmacology and pharmaceuticals (Fig. 4).

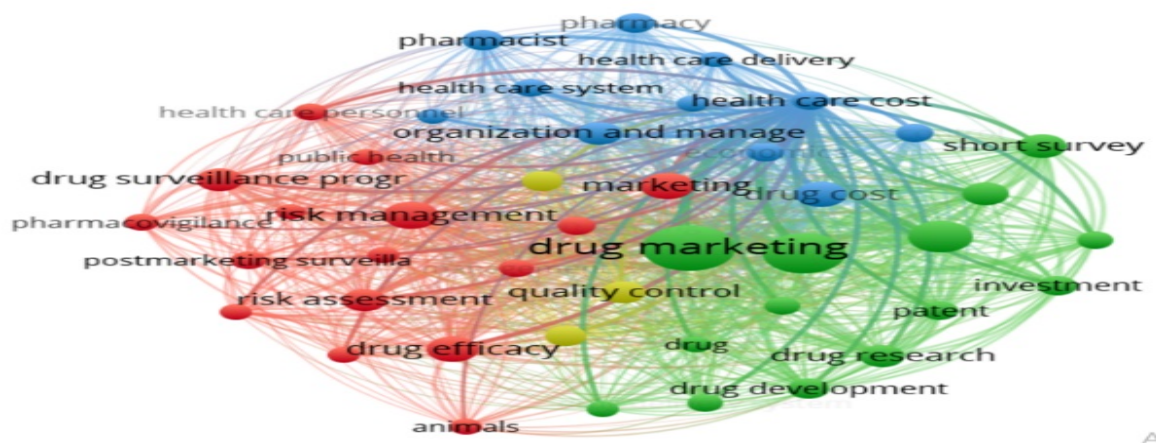

Figure 4. The findings of bibliometric analysis

Sources: developed by the authors based on Scopus data using the VOSviewer software tool.

The bibliometric analysis of scientific publications indexed by the Scopus database was conducted using the VOSviewer v.1.6.10 software. Table 1 shows four main intersectoral clusters of scientific research. They identify the essential issues of marketing management in the pharmaceutical industry.

Table 1. The intersectoral clusters of scientific researches

\begin{tabular}{|c|c|c|c|}
\hline № & Cluster 1 (16 items) & Cluster 2 (14 items) & Cluster 3 (11 items) \\
\hline 1. & Animals & Biotechnologies & Quality medicines \\
\hline 2. & Decision marketing & Commercial phenomenon & Pharmaceutical expensesQuality control \\
\hline 3. & Drug control & Medicines & Total quality management \\
\hline 4. & Drug efficacy & Drug delivery system & Health care \\
\hline 5. & Drug label & Drug design & Treatment costs \\
\hline 6. & Drug monitoring & $\begin{array}{l}\text { Pharmaceutical industry } \\
\text { development }\end{array}$ & Health care delivery \\
\hline 7. & Health care program & Pharmaceutical industry & Healthcare system \\
\hline 8. & Management & Pharmaceutical marketing & $\begin{array}{l}\text { Organization and } \\
\text { management }\end{array}$ \\
\hline 9. & Marketing & Pharmaceutical research & Pharmaceutic aid \\
\hline 10. & Pharmaceutical inspection & Financial management & Pharmacy \\
\hline 11. & Postmarketing surveillance & Investment & Pharmacist \\
\hline 12. & Risk assessment for society & Patent & \\
\hline 13. & Analysis of qualitative risks & Product development & \\
\hline 14. & Risk management factors & Quick delivery & \\
\hline 15. & Risk factors & & \\
\hline 16. & Risk factors in management & & \\
\hline
\end{tabular}

Sources: developed by the authors based on Scopus data using the VOSviewer software tool. 
V., Lazorenko, L., Saher, J., Jasnikowski. Web Management as a Marketing Management Determinant: Case for Pharmaceutical Enterprises

The first cluster combines the studies regarding marketing, management, and risk; the second - the pharmaceutical industry; the third - the housekeeper; the fourth - quality control. Figure 5 shows the relationship between marketing management in the pharmaceutical industry and the veterinary.

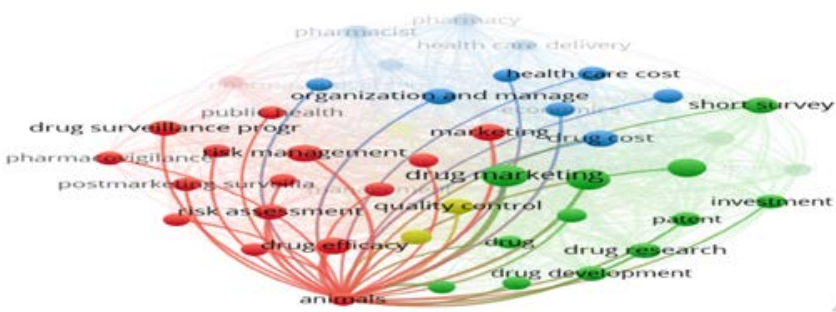

Figure 5. The research «animals» in the marketing management field

Sources: developed by the authors based on Scopus data using the VOSviewer software tool.

Figure 6 demonstrates the most productive countries investigating marketing management in the pharmaceutical field.

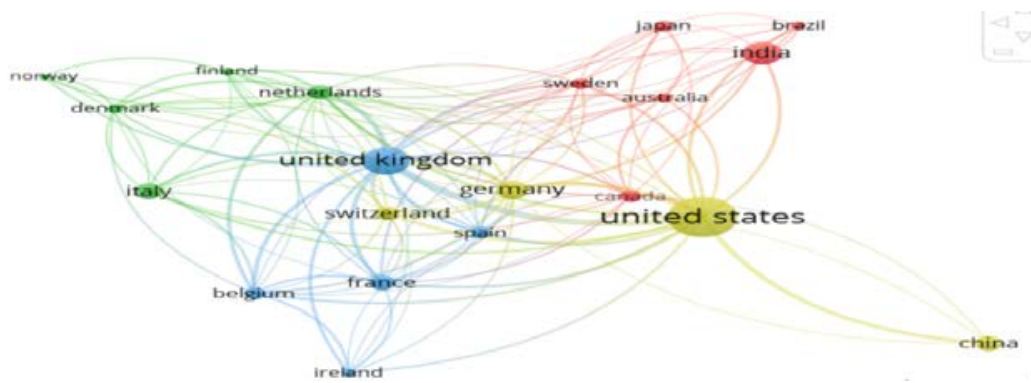

Figure 6. The results of bibliometric analysis by countries

Sources: developed by the authors based on Scopus data using the VOSviewer software tool.

The results showed that veterinary medicine is most often associated with drug efficacy, management, investment, risk, organization and management, patents, and quality control. Besides, this issue has been most actively studied by scientists from the United States, Britain, Germany, India, and Italy. Based on the results, it is appropriate to determine the most productive scientists such as J. Miller, G.S. Burrill, S. Milmo, S. Schmidt (American school); B. Chatterjee (Austrian school), D. Genneke, J. Wechsler (German school), N. Vishel Gapta (Australian school).

The systematization of scientific studies showed that many publications addressed the tools of digital marketing, their types, features of the application in various fields of economic activity, etc., including the importance of the site for enterprise development (Bozhkova et al., 2018; Davidaviciene et al., 2019; Illiashenko and Ivanova, 2015; Melnik et al., 2016; Mozgova, 2017; Oklander et al., 2020; Oklander and Oklander, 2017; Prudnikov and Nazarenko, 2021; Rosokhata, 2020; Teletov et al., 2020). The pharmaceutical companies' activities, the peculiarities of their actions, limitations, and opportunities that exist in the market were investigated by Mykhailiuk (2017); Chernousova and Mishchenko (2018); Shabelnyk (2016); Vitiuk and Trachenko (2018); Khazzaka (2019). However, there are next to no publications on analyzing the effectiveness of web management by pharmaceutical companies in the veterinary field. 

Pharmaceutical Enterprises

Methodology and research methods. This research involved the analysis of the websites and their management as one of the effective marketing tools. The study objects are the veterinary pharmaceutical companies, which are the leaders of the relevant market in Ukraine. For studying the population interest in the trends of web management and the pharmaceutical industry in the world and Ukraine, this paper analyzed trends in the dynamics of changes in the number of Google search queries of search engine users.

The next stage provided the bibliometric analysis. It allowed studying the degree of scientific interest regarding the research question. At the same time, the VOSViewer software tools enabled demonstrating the existing relationships between critical concepts studied by scientists from around the world in this field. The use of content analysis and comparative analysis allowed identifying the strengths and weaknesses of the primary web management tool for enterprises, on their basis to conclude the effectiveness of the sites of the largest producers of veterinary products in Ukraine.

Results. Each company and the business area operate in a specific competitive environment. Since almost all companies have their own websites, the Internet promotion strategy involves regular monitoring of the competitive environment. This type of audit allows identifying competing sites, determine their advantages and disadvantages during the analysis. In turn, it results in more effective company promotion and stronger competitive advantages.

The current competition covers new positions that did not exist 10 years ago. Nowadays, the main factor for assessing the company is its online presence. Large companies may use websites with a wide range of products, while small - with narrow landing pages or social networks. It stands to note that the landing page is a company laconic presentation on the Internet providing only information about the company, its activities, and a special sales offer. Thus, the landing page is best used for intermediaries in the products of biological factories, i.e., veterinary pharmacies or hospitals.

Regarding web management and product promotion of pharmaceutical companies with complicated products, it is more appropriate to use the website for online activities. Besides, all information on the website should be structured and understandable to potential customers. An important criterion is easy to understand information because the complicated product could be straightforward only to a limited number of people. Although most people who know about the product's effects are veterinarians, the site should be designed so that individuals without special education also understand it.

To determine web management effectiveness, this study involved the comparative analysis of competitors' websites in Ukraine viz Sumy Biological Factory (Sumy), Kherson Biological Factory (Kherson), and Biotestlab (Kyiv). the main criteria for competitive analysis of sites are as follows:

1. Usability (color-grade, font, image placement, downloading speed, and identity).

2. Website structure.

3. Website indexation.

4. Number of external pages.

5. Overall traffic.

6. Behavioral factors (bounce rate, pages per visit, time on the site).

7. Sources of traffic (direct, referrals, SEO, SMM, e-mail, and display advertising).

8. Adaptability to mobile devices.

This study was conducted in September 2020.

1. Usability. It stands to note that the main criterion of website usability for vaccine manufacturers is its identity. The website colors should match the corporate style:

- Sumy Biological Factory uses pastel blue colors, while all colors are mutually complementary. In turn, the photos are of good quality and unique, but the download speed is low. There are different conspicuous fonts. 

Pharmaceutical Enterprises

- Kherson Biological Factory has a landing page, which is very simple. The color scheme is repulsive since it is too much green. The photos are different in shape and format. 50\% of photos are downloaded from the Internet. The fonts on the website are different.

- Biotestlab differs among competitors. Its website is the most organized. The main page has a video screensaver with high download speed quickly and plays continuously. The website keeps the one style, different colors, but mostly light green.

2. Website structure. The website structure shows how convenient the site's main tabs are and how easy it is to find the necessary information. It should be ergonomic, i.e., easy to understand and search for the necessary information on the site:

- Sumy Biological Factory website structure is simple. It consists of the following main tabs: about the company, product catalog, cooperation, contract production, prices, and contacts.

- Kherson Biological Factory structure consists of the tab: main, products, about us, contacts. The structure is concise. There is not enough information to make a decision. There is no tap with pricing. The main page contains news dating back to 2017. However, if the company is presented as a landing page, it was necessary to place the basic information for potential customers, such as information about products and applications, prices, about the company, and contacts.

- Biotestlab structure consists of the following tabs: company, info center, production, products, and contacts. The structure is more concise and clearer. Notably, there is no price tab. The info center tab provides new product information.

3. Website indexation is the number of pages in a search engine. This study involved Google as the main search engine. Notably, the more pages, the more traffic could be driven to the webpage.

4. External pages are all sources that refer to the site. Notably, they are called link donors. The prominent donors could be suppliers, intermediaries, potential consumers, and customers. The more attractive company are on the Internet, the more potential customers are engaged. It stands to note that it is possible to interact and be a barter link donor.

5. Overall traffic shows the number of visitors. Since one visitor could visit the site several times, the overall traffic does not show the actual number of people who visited the site.

Table 2 demonstrates the findings of comparative analysis by website indexation, external pages, and overall traffic for investigated companies.

Therefore, Biotestlab is the leader by the number of pages in Google and overall traffic. It is worth indicating that traffic significantly depends on the city where the enterprise is located, how many farms are registered nearby, the work of sales managers, etc.

Table 2. Comparative analysis by a number of webpages

\begin{tabular}{llccc}
\hline \multicolumn{1}{c}{ Name } & \multicolumn{1}{c}{ URL } & $\begin{array}{c}\text { Number of } \\
\text { pages in } \\
\text { Google }\end{array}$ & $\begin{array}{c}\text { Number of } \\
\text { external } \\
\text { pages }\end{array}$ & $\begin{array}{c}\text { Overall } \\
\text { traffic }\end{array}$ \\
\hline Sumy Biological Factory & http://biofabrika.sumy.ua/ & 155 & 24 & 172 \\
Kherson Biological Factory & http://khersonbiofabrika.com/ & 59 & 5 & 420 \\
Biotestlab & https://www.biotestlab.ua/ & 692 & 26 & 11540 \\
\hline
\end{tabular}

Sources: developed by the authors based on (Spymetrics, 2021).

Table 3 demonstrates the findings of comparative analysis by bounce rate, pages per visit, and time on the site. Remarkably, the bounce rate shows the situation when the visitor visited only the main page. Pages per visit inform how many pages were opened by the visitor before leaving the site. 
V., Lazorenko, L., Saher, J., Jasnikowski. Web Management as a Marketing Management Determinant: Case for Pharmaceutical Enterprises

Table 3. Behavioral factors of visitors

\begin{tabular}{|c|c|c|c|c|}
\hline \multirow[t]{2}{*}{ Name } & \multirow[t]{2}{*}{ Competitors } & \multicolumn{3}{|c|}{ Behavioral factors } \\
\hline & & Boun & $\mathrm{Pag}$ & it Time \\
\hline Sumy Biological Factory & http://biofabrika.sumy.ua/ & $68 \%$ & 3,1 & $58 "$ \\
\hline Kherson Biological Factory & http://khersonbiofabrika.com/ & $66 \%$ & 2,5 & $32 "$ \\
\hline Biotestlab & https://www.biotestlab.ua/ & $59 \%$ & 1,88 & 1'42" \\
\hline
\end{tabular}

Sources: developed by the authors based on (Spymetrics, 2021).

The bounce rates of the studied companies are good for the veterinary field since they do not have a direct button «Buy» or «Order». Sumy Biological Factory has the best value of indicator «Pages per visit». That could result from gaining all the necessary information in many steps, or the consumer is interested to learn more about the vaccine factory.

On the other hand, the indicator «Time on the site» is the best behavioral factor to show how much a potential customer enjoys a site. In this case, Biotestlab is the most competitive. Its statistics are underlined by the high interest of international contractors who spent a long time on the site. In turn, the opposite situation could indicate that all the necessary information place firstly.

The traffic is provided by six main sources such as direct visits; referrals (transitions from other sites); SEO (organic search); SMM (transitions from social networks); e-mail (transitions from e-mail); display advertising (the transition from other sites, namely through contextual advertising). Table 4 demonstrates all traffic sources for the analyzed enterprises.

Table 4. Sources of traffic

\begin{tabular}{lcccccc}
\hline Name & \multicolumn{5}{c}{ Traffic sources, \% } \\
& Direct & Referrals & SEO & SMM & E-mail & Display ads \\
\hline Sumy Biological Factory & 37,94 & 0 & 56,11 & 5,96 & 0 & 0 \\
Kherson Biological Factory & 0 & 25,85 & 48,3 & 25,85 & 0 & 0 \\
Biotestlab & 14,72 & 0,22 & 84,36 & 0,7 & 2 & 0 \\
\hline
\end{tabular}

Sources: compiled by the authors based on (Spymetrics6 2021).

The findings showed that Sumy and Kherson factories use only $50 \%$ of Internet promotion capacity to attract more traffic. Direct visits could determine customer loyalty. All websites are optimized to find them quickly. They are ranked 1st in the Google search engine. Therefore, it is most likely that a visitor would go to this site from search engines since people usually follow the first links.

The company URL should be easy to remember. All companies follow this rule. On the other hand, the location of the site in organic search has essential value. A user who does not notice the website among the first five search results in Google (maximum first page) would not look further. Then, the user concludes that the site doesn't exist. The obtained results showed that the analyzed enterprise takes first place in search results.

The best SMM efficiency is observed in the «Kherson Biofactory». Mostly, the conversions are provided by the page and intermediaries posting the information in their accounts. The referral statistics indicate many references to this factory. Therefore, a good relationship could be assumed between the company's employees, intermediaries, suppliers, and customers. In turn, Sumy Biofactory is not represented on social networks, while it has a high percentage of traffic sources. This reaction could result from discussions on the products by target customers on different social media pages. Table 5 shows the presence of the studied companies in social networks. 
V., Lazorenko, L., Saher, J., Jasnikowski. Web Management as a Marketing Management Determinant: Case for Pharmaceutical Enterprises

Table 5. Availability of biological factories accounts in social networks

\begin{tabular}{ll}
\multicolumn{1}{c}{ Competitors } & SMM \\
\hline Sumy Biological Factory & Facebook \\
Kherson Biological Factory & Facebook \\
Biotestlab & Facebook \\
\hline
\end{tabular}

Sources: developed by the authors.

Sumy Biological Factory has been presented on the social network for one year. Notably, the representation of Biotestlab and Kherson Biological Factory significantly impacts the individuals' awareness about the company.

The most straightforward traffic source is e-mail marketing aimed at legal entities that are present in the veterinary. It is easy to find e-mail addresses of farms and veterinary pharmacies to send them the sales proposition. Notably, it is essential to send different messages to particular target buyers depending on the animal species and their number on the farm.

Biotestlab demonstrates the high effectiveness of using the Internet to promote products. The company uses the maximum number of sources (direct, referrals, SEO, SMM, and e-mail).

Generally, developed sites use all six traffic sources in their activities. Remarkably, display advertising on the Internet is not used in Ukraine since it is inexpedient for the general public. Therefore, there is no need to use it. To fully comply with the innovative development in advertising management, it is essential to adapt websites for mobile versions. Table 6 summarizes the above findings.

Table 6. The summary of competitive analysis

\begin{tabular}{|c|c|c|c|}
\hline Indicators & Sumy Biological Factory & $\begin{array}{c}\text { Kherson Biological } \\
\text { Factory }\end{array}$ & Biotestlab \\
\hline Usability & 2 place & 3 place & 1 place \\
\hline Website structure & 1 place & 3 place & 2 place \\
\hline Website indexation & 155 & 59 & 692 \\
\hline Number of external pages & 24 & 5 & 26 \\
\hline Overall traffic & 172 & 420 & 11540 \\
\hline \multicolumn{4}{|l|}{ Behavioral factors: } \\
\hline Bounce Rate & $68 \%$ & $66 \%$ & $59 \%$ \\
\hline Pages per visit & 3,1 & 2,5 & 1,88 \\
\hline Time On Site & $58^{\prime \prime}$ & $32^{\prime} '$ & $1^{\prime} 42^{\prime \prime}$ \\
\hline \multicolumn{4}{|l|}{ Traffic sources, \%: } \\
\hline Direct & 37,94 & 0 & 14,72 \\
\hline Referrals & 0 & 25,85 & 0,22 \\
\hline SEO & 56,11 & 48,3 & 84,36 \\
\hline SMM & 5,96 & 25,85 & 0,7 \\
\hline E-mail & 0 & 0 & 2 \\
\hline Display advertising & 0 & 0 & 0 \\
\hline Adapting for mobile devices & + & - & + \\
\hline
\end{tabular}

Sources: developed by the authors based on (Spymetrics, 2021).

Thus, all Ukrainian biological vaccines companies for animals are represented on the Internet. The findings showed that only «Biotestlab» effectively promotes products on the Internet. It uses direct sources, referrals, SEO, SMM, and e-mail. In second place is the Sumy Biological Factory, and in the last Kherson Biological Factory.

Conclusions. The Internet is becoming an integral part of enterprises' marketing and commercial policy, regardless of business area, ownership, and the scale of business transactions. 

Pharmaceutical Enterprises

Internet marketing requires a systematic approach such as setting specific goals, choosing the means and pricing models of advertising performance evaluation, analyzing results, developing recommendations to strengthen their position in the electronic market.

After introducing innovation, efficiency would be insignificant for the first period. The target audience is 35 to 65 years old veterinarians who do not have time to buy the vaccine through websites. Therefore, online commerce would be aimed at the niche of customers looking for reviews and recommendations when choosing a vaccine supplier. Besides, it is necessary to ensure a convenient online profile for intermediaries.

Thus, the above shows that pharmaceutical companies follow global trends. All Ukrainian biological vaccines companies for animals are represented on the Internet. Each site has its own competitive indicators according to specific criteria, but the most competitive is Biotestlab. In second place is the Sumy Biological Factory. On the last Kherson Biological Factory.

The findings showed that virtually every company and activity have its own competitive environment, relevant sites, etc. Therefore, the business promotion strategy on the Internet involves regular analysis. The main comparative indicators of sites' competitive analysis are as follows: usability, website structure, website indexation, number of external pages, overall traffic, behavioral factors (bounce rate, pages per visit, time on site), traffic sources (direct, referrals, SEO, SMM, e-mail and pages per visit, display advertising) and adaptability to the mobile devices.

Author Contributions: conceptualization, V. L., and L. S.; methodology, V. L.; validation, V. L. and L. S.; formal analysis, V. L. and A. J.; resources, V. L.; writing-original draft preparation, V. L., L. S. and A. J.; writing-review and editing, L. S.; visualization, V. L.; supervision, L. S.

Funding: This research received no external funding.

\section{References}

Ain.ua. (2021). Official web page. Retrieved from [Link]

Bozhkova, V. V., Ptashchenko, O. V., Saher, L. Y., \& Syhyda, L. O. (2018). Transformation of marketing communications tools in the context of globalization. Marketing and management of innovations, (1), 73-82. [CrossRef]

Chernousova, Zh. T., \& Mishchenko, A. P. (2018). Economic analysis of the pharmaceutical enterprise on the perspective of innovative development at the example of farmak JSC Economic bulletin of National technical university of Ukraine «Kyiv polytechnic institute», 15. [Google Scholar] [CrossRef].

Davidaviciene, V., Meidute-Kavaliauskiene, S., \& Paliulis, R. (2019). Research on the influence of social media on generation Y consumer purchase decisions. Marketing and Management of Innovations, 4, 39-49. [Google Scholar] [CrossRef]

Gemius Ukraine (2021). Official web page. Retrieved from [Link]

Horoshop (2021). Official web page. Retrieved from [Link]

Illiashenko, S. M., \& Ivanova, T. Y. (2015). Internet promotion tools and techniques: Analytical review. Marketing and Management of Innovations, (3), 20-32. Retrieved from [Link]

Indigo (2021).Official web page. Retrieved from [Link]

Khazzaka, M. (2019). Pharmaceutical marketing strategies' influence on physicians' prescribing pattern in Lebanon: ethics, gifts, and samples. BMC Health Services Research, 19(1). [CrossRef

LuxSite (2021). Official web page. Retrieved from [Link]

Melnik, Y. M., Saher, L. Y., Illiashenko, N. S., \& Ryazantseva, Y. M. (2016). Classification of basic forms and types of marketing on-line communications. Marketing and management of innovations, (4), 43-55. Retrieved from [Link]

Mozgova, G. V., \& Boiko, Y. A. (2017). Site as internet marketing tool. Economy and Society, 3, 523-528.

Mykhailiuk, M. A. (2017). Slept-analysis as a method of strategic investigation of pharmaceutical companies. Scientific Bulletin of Kherson State University. Series «Economic Sciences», 25(1), 174-177.

Oklander M., \& Oklander T. (2017). Segmentation and communication in digital marketing. Marketing and Management of Innovations, 3, 69-78. [Google Scholar] [CrossRef]

Oklander, M., \& Wierzbik-Strońska, M. (2020). Marketing Technologies of Business Development: monograph. Katowice: Wydawnictwo Wyższej Szkoły Technicznej w Katowicach. Retrieved from [Link]

Prudnikov, Yu., \& Nazarenko, A. (2021). The role of content marketing in the promotion of medical goods and services. Health Economics and Management Review, 2(1), 23-29. [Google Scholar] [CrossRef] 
V., Lazorenko, L., Saher, J., Jasnikowski. Web Management as a Marketing Management Determinant: Case for Pharmaceutical Enterprises

Rosokhata, A. S., Rybina, O. I., Derykolenko, A. O., \& Makerska, V. (2020). Improving the Classification of Digital Marketing Tools for the Industrial Goods Promotion in the Globalization Context. Research in World Economy, 11 (4), 42-52. [Google Scholar] [CrossRef]

Shabelnyk, T. V. (2016). Klasyfikatsiia osnovnykh subiektiv ta obiektiv suchasnoho farmatsevtychnoho rynku Ukrainy [Classification of the main subjects and objects of the modern pharmaceutical market of Ukraine]. Business inform, (4), 289-293.

Spymetrics (2021). Official web page. Retrieved from [Link]

Sumy biological factory. (2021). Official web page. Retrieved from [Link]

Teletov, A., Teletova, S., Letunovska, N., \& Lazorenko, V. (2020). Innovations in Online Advertising Management of Ukrainian Business Entities. International Journal, 9(1.2). [Google Scholar] [CrossRef]

Vitiuk A. V., \& Trachenko K. R. (2018). Supplementary trends in development of the pharmaceutical industry of Ukraine. Visnyk of Vinnytsia Polytechnical Institute, 6, 35-43. [CrossRef].

Валерія Лазоренко, Суми, Україна

Людмила Сагер, к.е.н., доцент, Сумський державний університет, Україна

Адам Ясніковскі, Бистриия Клодзька, Польща

Вебменеджмент як детермінанта маркетингового менеджменту фармацевтичного підприємства

Основною метою дослідження є здійснення конкуреного аналізу вебсайтів українських підприємств ветеринарної галузі як однієї із ключових детермінант маркетингового менеджменту. Об'єктом дослідження є найбільші підприємства України з виробництва продукції ветеринарного призначення. Методичним інструментарієм проведеного дослідження стали методи трендового, бібліометричного (з використанням інструментарію VOSViewer v.1.6.10), порівняльного, контент-аналізу. Період здійснення аналізу - вересень 2020 р. Результати трендового аналізу показують сталий інтерес у світі до питання веб менеджменту, в Україні - наявність значних коливань від повної відсутності запитів в окремі періоди за останні 5 років до суттєвого зростання (відповідно від 0 до 100\%). Пошукові запити за «рharmaceutics» у світі поступово зростають, тоді як в Україні недостатня кількість пошуків, щоб навести статистику. За результатами бібліометричного аналізу наукових напрацювань з досліджуваної тематики, визначено чотири основні напрямки наукових досліджень, а саме: 1) маркетинг, управління та ризикологія; 2) ффармацевтична галузь; 3) економка; 4) контроль якості. Найчастіше тему ветеринарії пов'язують з ефективністю лікарських засобів, менеджментом, інвестуванням, управлінням, ризиками, організацією та менеджментом, патентами та контролем якості. Найбільш активно дане питання досліджувалося вченими зі США Великобританії, Німеччини, Індії та Італії. Практично кожна компанія і сфрера діяльності має своє конкурентне середовище, відповідні сайти та т. ін., тому стратегія просування бізнесу в Інтернеті передбачає періодичний аналіз. У роботі застосовано наступні порівняльні показники конкурентного аналізу сайтів: юзабіліті, структура сайту, індексація сайту, кількість зовнішніх сторінок, загальний трафік, поведінкові фрактори (відмови, глибина сторінки, час проведення на сайті), джерела трафіку (прямі заходи, реферали, SEO, SMM, E-mail та банерна реклама) та пристосованість до мобільної версії. За результатами аналізу визначено, що всі українські виробники біологічних вакцин для тварин представлені в мережі Інтернет. Встановлено, що лише «Біотестлаб» ефективно використовує Інтернет для просування продукції. На другому місці знаходиться «Сумська біологічна фабрика», тоді як на останньому - «Херсонська біологічна фабрика».

Ключові слова: маркетинг, вебменеджмент, детермінанта, підприємство, сайт, конкурентний аналіз. 